\title{
KREATIVITAS, GAYA KEPIMPINAN DAN KOMPETENSI DALAM MEMBENTUK KEPUASAN KERJA KARYAWAN
}

\author{
Onny Juwono ${ }^{1}$; Yuliana Wangsadinata ${ }^{2}$ \\ ${ }^{1}$ Jurusan Manajemen Pemasaran, Universitas Budi Luhur, \\ Jl. Ciledug Raya Petukangan Utara Jakarta Selatan \\ ${ }^{2}$ Universitas Bina Nusantara \\ onny_juwono2008@yahoo.com
}

\begin{abstract}
The purpose of this research is to analyze the influence of creativity, leadership style, and competence on employee job satisfaction. The method used in this study is the Pearson Correlation, Multiple Regression, and Path Analysis. Data obtained from the employee appraisal by filling in the questionnaire that has been provided by using a Likert scale. The results achieved in this research is creativity (0.828), leadership style (0.962) and competence (0.946) has a strong correlation with employee job satisfaction. It is expected that the results of this research can provide input for PT Interdata Bhakti Mulya in general and leadership in particular so as to improve the performance of the company in years to come.
\end{abstract}

Keywords: creativity, leadership style, competence, employee job satisfaction

\begin{abstract}
ABSTRAK
Tujuan penelitian adalah menganalisis pengaruh kreativitas, gaya kepemimpinan, dan kompetensi terhadap kepuasan kerja karyawan. Metode yang digunakan dalam penelitian ini adalah Korelasi Pearson, Regresi Berganda, dan Analisis Jalur. Data diperoleh dari penilaian karyawan dengan mengisi kuesioner yang telah disediakan dengan menggunakan skala Likert. Hasil yang dicapai dalam penelitian ini adalah kreativitas (0.828), gaya kepemimpinan (0.962) dan kompetensi (0.946) mempunyai hubungan yang kuat terhadap kepuasan kerja karyawan. Diharapkan hasil penelitian ini dapat memberikan masukan bagi PT Interdata Bhakti Mulya secara umum dan pimpinan pada khususnya sehingga dapat meningkatkan kinerja perusahaan di tahun yang akan datang.
\end{abstract}

Kata kunci: kreativitas, gaya kepemimpinan, kompetensi, kepuasan kerja karyawan 


\section{PENDAHULUAN}

Organisasi secara serius bertanggung jawab terhadap manajemen sumber daya manusianya. Hal ini untuk mencapai kinerja dalam perusahaan menjadi meningkat serta memperoleh dan mempertahankan karyawan yang mempunyai kreativitas tinggi atau berkompeten, guna menjadi penentu keberhasilan dalam manajemen. Kendala yang dihadapi oleh perusahaan, yaitu sulitnya mengidentifikasi apakah sumber daya manusia yang mereka miliki mempunyai kemampuan yang memadai atau tidak dalam menjalankan fungsinya pada perusahaan; di antaranya meliputi beberapa faktor yang sulit diidentifikasi di PT Interdata Bhakti Mulya, yaitu kreativitas, penerapan gaya kepemimpinan, dan kompetensi yang dirasa sukar untuk diidentifikasi.

Model kompetensi akan memberikan gambaran yang sangat jelas tentang tuntutan kompetensi yang harus dimiilki seseorang serta dapat dibandingkan dengan standar ketentuan sebagai tolak ukur. Karena kompetensi berfokus pada karakteristik pribadi serta kompetensi spesifik setiap fungsi jabatan yang dimilki pemegang fungsi jabatan tersebut, untuk dapat dikatakan mempunyai kualifikasi pada jabatan tersebut. Untuk menghasilkan tenaga kerja yang professional, selain memerlukan peran individu yang memiliki kreativitas, juga memerlukan gaya kepemimpinan yang baik yang diberikan oleh seorang pemimpin karena pemimpin yang baik dapat memberikan contoh yang baik pula untuk karyawan atau bawahannya. Dengan demikian, diperlukan adanya peran dari organisasi. Oleh sebab itu, perusahaan diharapkan mampu mendapatkan sumber daya manusia yang kompetitif.

Berdasarkan hal tersebut, maka didapat hal-hal yang hendak diinvestigasi, yaitu bagaimana penilaian karyawan terhadap kreativitas, gaya kepemimpinan yang diterapkan oleh pimpinan, dan kompetensi pada perusahaannya, bagaimana pengaruh kreativitas terhadap kepuasan kerja karyawan secara parsial, bagaimana pengaruh gaya kepemimpinan terhadap kepuasan kerja karyawan secara parsial, bagaimana pengaruh kompetensi terhadap kepuasan kerja karyawan secara parsial, dan bagaimana pengaruh kreativitas, gaya kepemimpinan, dan kompetensi terhadap kepuasan kerja karyawan secara simultan.

Tujuan dari penelitian ini adalah untuk mengetahui penilaian karyawan terhadap kreativitas perusahaan, penilaian karyawan terhadap gaya kepemimpinan yang diterapkan oleh pimpinan, penilaian karyawan terhadap kompetensi, menganalisis pengaruh kreativitas terhadap kepuasan kerja karyawan secara parsial, menganalisis pengaruh gaya kepemimpinan terhadap kepuasan kerja karyawan secara parsial, menganalisis pengaruh kompetensi terhadap kepuasan kerja karyawan secara parsial, dan menganalisis pengaruh kreativitas, gaya kepemimpinan, dan kompetensi terhadap kepuasan kerja karyawan secara simultan.

Kreativitas didefinisikan secara berbeda-beda (Dedi Supriadi, 1994). Keberagaman definisi itu, sehingga pengertian kreativitas itu tergantung pada bagaimana orang mendefinisikannya "creativity is a matter of definition". Pada intinya, kreativitas adalah kemampuan seseorang untuk melahirkan sesuatu yang baru, baik berupa gagasan maupun karya nyata, yang relatif berbeda dengan apa yang telah ada sebelumnya. Penentuan kriteria kreativitas menyangkut 2 dimensi, yaitu (1) Dimensi proses, merupakan segala produk yang dihasilkan dari proses yang dianggap sebagai produk kreatif. Kriteria produk yang dianggap sebagai produk kreatif menunjuk pada hasil perbuatan, kinerja, atau karya seseorang dalam bentuk barang atau gagasan; (2) Dimensi person, sering dikatakan sebagai kepribadian kreatif, yang meliputi dimensi kognitif (bakat) dan dimensi non-kognitif (minat, sikap, dan kualitas tempramental). Dapat disimpulkan bahwa orang-orang kreatif memiliki ciri-ciri kepribadian yang signifikan dan berbeda dari orang-orang yang kurang kreatif.

Sedangkan menurut Kartini Kartono (2006), gaya kepemimpinan diartikan sebagai suatu pola perilaku manajemen profesional yang dirancang untuk memadukan minat dan usaha pribadi serta 
organisasi untuk mencapai tujuan. Ada 3 macam kepemimpinan, yaitu (1) Kepemimpinan Authoritarian (Authocratic), di mana pemimpin mengutamakan kekuatan dari posisi formalnya seperti kurang memperhatikan kebutuhan bawahan, lebih menciptakan penyelesaian tugas, semua aktivitas ditentukan oleh atasan, dan komunikasi hanya satu arah atau ke bawah saja; (2) Kepemimpinan Partisipaty (Democratie), yakni melibatkan bawahan dalam perencanaan / pengambilan keputusan, lebih memperhatikan kepada bawahan, mencapai tujuan organisasi, dan menekankan 2 hal, yaitu bawahan dan tugas; (3) Kepemimpinan Laissez-faire yang merupakan kebalikan dari gaya kepemimpinan yang pertama. Di sini pemimpin membiarkan bawahnnya untuk mengatur dirinya sendiri, dan manajer hanya menentukan kebijaksanaan dari tujuan umum serta bawahan dapat mengambil keputusan yang relevan dan mencapai tujuan dalam segala hal yang mereka anggap cocok.

Ada 6 ciri yang terkait dengan kepemimpinan (Robbins dan Coulter, 2005:129) di antaranya adalah (1) Dorongan. Pemimpin menunjukkan tingkat usaha yang tinggi, dan mereka relatif mempunyai kehendak yang tinggi akan pencapaian prestasi. Mereka ambisius, mempunyai banyak energi, dan tidak mengenal lelah dalam kegiatannya serta menunjukkan inisiatif; (2) Kehendak untuk memimpin. Pemimpin mempunyai kehendak yang kuat untuk mempengaruhi dan memimpin orang lain. Mereka menunjukkan kemauan untuk mengemban tanggung jawab; (3) Kejujuran dan integritas. Pemimpin membangun hubungan saling mempercayai antara mereka sendiri dan pengikutnya dengan menjadi jujur dan tidak menipu serta dengan menunjukkan konsistensi yang tinggi antara perkataan dan perbuatan; (4) Kepercayaan diri. Pemimpin perlu menunjukkan kepercayaan diri untuk meyakinkan pengikutnya tentang kebenaran sasaran dan keputusannya; (5) Kecerdasan. Pemimpin haruslah cukup cerdas untuk mengumpulkan, menganalisis dan menafsirkan banyak informasi. Mereka juga perlu untuk mampu menciptakan visi, memecahkan masalah, dan membuat keputusan yang tepat; (6) Pengetahuan yang terkait dengan pekerjaan. Pemimpin yang efektif mempunyai tingkat pengetahuan yang tinggi tentang perusahaan, industri, dan hal-hal teknis. Pengetahuan yang mendalam membuat pemimpin dapat membuat keputusan yang terinformasi dengan baik dan memahami akibat dari keputusan itu.

Menurut Loma yang dikutip dari http://www.e-psikologi.com/manajemen/111202.html, kompetensi didefinisikan sebagai aspek-aspek pribadi dari seorang pekerja, yang memungkinkan dia untuk mencapai kinerja yang superior. Aspek-aspek pribadi ini termasuk sifat, motif, sistem nilai, sikap, pengetahuan, dan keterampilan. Kompetensi-kompetensi akan mengarahkan tingkah laku, sedangkan tingkah laku akan menghasilkan kinerja. Kompetensi juga dapat diartikan (http://www.schoonover.com/competency faqs.html) sebagai suatu tingkah laku atau setiap tingkah laku yang mendeskripsikan suatu kinerja yang baik dari suatu konteks pekerjaan.

Kompetensi didefinisikan berbeda-beda menurut beberapa pandangan. Berikut ini adalah beberapa pandangan tentang kompetensi. Pertama, Behaviourist. Pandangan ini mendeskripsikan kompetensi sebagai suatu standar kinerja yang diperlukan untuk mencapai standar kinerja yang telah ditetapkan. Pandangan ini dikemukakan oleh Paviiov (Rusia) dan Thomdike \& Skinner (Amrika Serikat). Pandangan ini hanya melihat segala sesuatu yang dapat diamati melalui observasi. Kedua, Constructivist. Pandangan ini mendefinisikan kompetensi dalam hubungannya dengan hasil pekerjaan yang didasari oleh karakteristik sesorang tersebut, yaitu kualitas, attitude, dan nilai. Pandangan ini merupakan cabang dari psikologi kognitif yang didasari oleh penelitian Jean Piaget (Perancis) dan Vygotsky (Rusia) dan berfokus pada proses mental. Inti dari pandangan ini adalah individu membangun pengetahuan mereka dari hasil pengamatan dan pemahaman mereka terhadap kinerja lain. (Robbins dan Coulter, 2005:129) (Robbins dan Coulter, 2005:129). Ketiga, SMR Viewpoint. Definisi kompetensi adalah penerapan pengetahuan attitude, motif, nilai behaviour ataupun karakteristik lain, sampai pada standar yang ditetapkan untuk menghasilkan produk dan jasa.

Kepuasan kerja adalah sikap umum terhadap pekerjaan seseorang, yang menunjukkan pembedaan antara jumlah penghargaan yang diterima pekerja dan jumlah yang mereka yakini seharusnya mereka terima (Robbins 2003:78 ) dan Wibowo (2007:299). Kemudian, Wibowo 
(2007:300) berpendapat bahwa kepuasan kerja memiliki 2 teori mengenai kepuasan kerja dalam pendapatnya. Dikatakan bahwa teori kepuasan kerja mencoba mengungkapkan apa yang membuat sebagian orang lebih puas terhadap pekerjaannya dari beberapa lainnya. Teori ini juga mencari landasan tentang proses kepuasan orang terhadap kepuasan kerja. Di antara teori kepuasan kerja adalah (1) Two-factor theory, merupakan teori kepuasan kerja yang menganjurkan bahwa kepuasan dan ketidakpuasan merupakan bagian dari kelompok variabel yang berbeda, yaitu motivators dan hygiene factors; dan (2) Value theory. Menurut konsep teori ini, kepuasan kerja terjadi pada tingkat di mana hasil pekerjaan diterima individu seperti yang diharapkan. Semakin banyak orang menerima hasil, akan semakin puas. Semakin sedikit mereka menerima hasil, akan menjadi kurang puas.

Menurut Kreitner dan Knicki (2007) dalam Wibowo (2007:302), terdapat 5 faktor yang dapat mempengaruhi timbulnya kepuasan kerja di antaranya (1) Need fulfillment (pemenuhan kebutuhan). Model ini dimaksudkan bahwa kepuasan ditentukan oleh tingkat karakteristik pekerjaan memberikan kesempatan pada individu untuk memenuhi kebutuhan hidupnya; (2) Discrepancies (perbedaan). Model ini menyatakan bahwa kepuasan merupakan suatu hasil memenuhi harapan; (3) Value attainment (pencapaian nilai). Gagasan model ini adalah bahwa kepuasan merupakan hasil dari persepsi pekerjaan memberikan pemenuhan nilai kerja individual yang penting; (4) Equity (keadilan). Dalam model ini dimaksudkan bahwa kepuasan merupakan fungsi dari seberapa adil individu diperlakukan di tempat kerja; (5) Dispositional/genetic components (komponen genetik). Model ini didasarkan pada keyakinan bahwa kepuasan kerja sebagian merupakan sifat pribadi dan faktor genetik.

\section{METODE PENELITIAN}

Instrumen pengukuran yang digunakan dalam penelitian ini adalah sebagai berikut (lihat Tabel $1)$.

Tabel 1 Operasionalisasi Variabel Penelitian

\begin{tabular}{|c|c|c|c|c|}
\hline Variabel & Sub Variabel & Indikator & Ukuran & Pengujian \\
\hline X1. Kreativitas & 2. Dimensi person & $\begin{array}{l}\text { 1. karya baru } \\
\text { 2. pemberian manfaat } \\
\text { 3. penyelesaian masalah } \\
\text { 1.terbuka terhadap pengalaman } \\
\text { baru } \\
\text { 2. percaya diri } \\
\text { 3. luwes dalam berpikir dan } \\
\text { bertindak }\end{array}$ & $\begin{array}{l}\text { Data Ordinal yang } \\
\text { ditransform menjadi } \\
\text { data Interval }\end{array}$ & Skala Likert \\
\hline $\begin{array}{l}\text { X2.Gaya } \\
\text { Kepemimpinan }\end{array}$ & 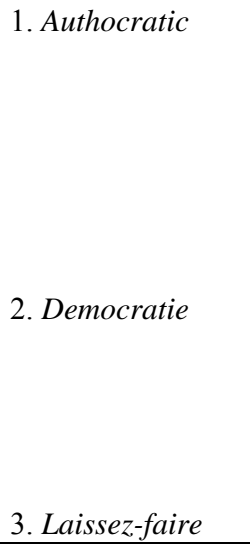 & $\begin{array}{l}\text { 1. kurang perhatian pada } \\
\text { bawahan } \\
\text { 2. mementingkan penyelesaian } \\
\text { tugas } \\
\text { 3. aktivitas ditentukan atasan } \\
\text { 4. komunikasi satu arah } \\
\text { 1. melibatkan bawahan } \\
\text { 2. memperhatikan bawahan } \\
\text { 3. komunikasi } 2 \text { arah } \\
\text { 4. terbuka } \\
\text { 1. kaku dalam berkomunikasi } \\
\text { 2. bertindak sesuai prosedur } \\
\text { 3. tunduk pada peraturan } \\
\text { 4. karyawan dapat mengambil } \\
\text { keputusan dalam situasi tertentu }\end{array}$ & $\begin{array}{l}\text { Data Ordinal yang } \\
\text { ditransform menjadi } \\
\text { data Interval }\end{array}$ & Skala Likert \\
\hline
\end{tabular}


Tabel 1 Operasionalisasi Variabel Penelitian (lanjutan)

\begin{tabular}{|c|c|c|c|c|}
\hline Variabel & Sub Variabel & Indikator & Ukuran & Pengujian \\
\hline X3. Kompetensi & $\begin{array}{l}\text { 2. Constructivist } \\
\text { 3. SMR Viewpoint }\end{array}$ & $\begin{array}{l}\text { 1. pencapaian kinerja } \\
\text { 2. deskripsi tugas } \\
\text { 3. hasil pekerjaan } \\
\text { 1. kualitas } \\
\text { 2. konsep diri dan nilai-nilai } \\
\text { 3. perilaku } \\
\text { 1. pengetahuan } \\
\text { 2. ketrampilan } \\
\text { 3. kinerja diatas rata-rata }\end{array}$ & $\begin{array}{l}\text { Data Ordinal yang } \\
\text { ditransform menjadi } \\
\text { data Interval }\end{array}$ & Skala Likert \\
\hline $\begin{array}{l}\text { Y.Kepuasan kerja } \\
\text { Karyawan }\end{array}$ & 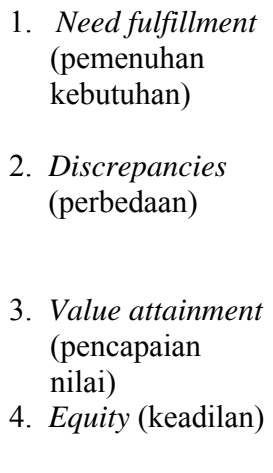 & $\begin{array}{l}\text { 1. rasa aman } \\
\text { 2. kepuasan terhadap atasan } \\
\text { 3. kompensasi } \\
\text { 1. pekerjaan berbeda dari } \\
\quad \text { sebelumnya } \\
\text { 2. promosi } \\
\text { 3. supervisi } \\
\text { 1. benefit } \\
\text { 2. reward } \\
\text { 3. peraturan } \\
\text { 1. Coworkers } \\
\text { 2. Nature of work } \\
\text { 3. komunikasi }\end{array}$ & $\begin{array}{l}\text { Data Ordinal yang } \\
\text { ditransform menjadi } \\
\text { data Interval }\end{array}$ & Skala Likert \\
\hline
\end{tabular}

Teknik pengumpulan data yang digunakan adalah wawancara, yaitu teknik pengumpulan data yang dilakukan melalui pertanyaan terstruktur. Dalam hal ini dengan manajemen sumber daya manusia pada PT Interdata Bhakti Mulya mengenai manajemen sumber daya manusia yang berkaitan dengan kreativitas, gaya kepemimpinan, kompetensi terhadap kepuasan kerja karyawan.

Selain itu, peneliti melakukan riset kepustakaan yang berhubungan dengan masalah yang diteliti melalui buku-buku, literatur, internet dan sumber data lainnya di dalam perpustakaan. Riset kepustakaan yang dilakukan terutama yang berhubungan sumber daya manusia.

Populasi penelitian yang dilakukan oleh SDM PT Interdata Bhakti Mulya terdiri dari berbagai SDM, dengan berbagai latar belakang dan pekerjaan yang berbeda. Penarikan sampel untuk penelitian ini dilaksanakan pada bulan Mei 2009, dengan membagi sejumlah kuisioner kepada SDM yang bekerja di PT Interdata Bhakti Mulya. Penentuan jumlah sampel pada penelitian ini menggunakan tekhnik sampel Slovin, di mana populasinya adalah SDM pada PT Interdata Bhakti Mulya.

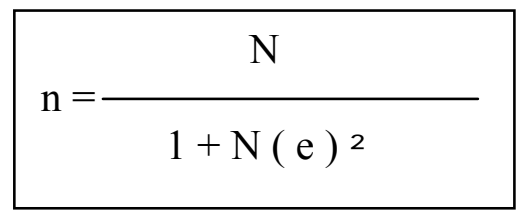

Di mana :

$\mathrm{n}=$ ukuran sampel

$\mathrm{N}=$ ukuran populasi

$\mathrm{e}=$ nilai kritis

Dengan demikian, didapat nilai $\mathrm{e}=5 \%(0,05)$ sehingga didapatkan $\mathrm{e}^{2}=0,0025$. Maka berdasarkan rumus di atas, didapatkan jumlah sampel sebagai berikut: 
$\mathrm{n}=$

$\frac{50}{1+50(0,0025)}$

$\mathrm{n}=44,44 \approx 45$ responden

Setelah didapatkan jumlah responden, maka penelitian mulai dilakukan dengan membagikan kuisioner kepada 45 responden, yakni karyawan pada PT Interdata Bhakti Mulya. Adapun metode untuk menganalisis data adalah Pearson Product Moment (PPM) dan Path Analysis. Pearson Product Moment digunakan untuk mengetahui derajat hubungan antara variabel bebas (independent) dengan variabel terikat (dependent). Rumus yang digunakan Korelasi PPM (sederhana) adalah:

$$
\operatorname{rxy}=\quad \frac{n\left(\sum X Y\right)-\left(\sum X\right) \cdot\left(\sum Y\right)}{\sqrt{\left[n \cdot \sum X^{2}-\left(\sum X\right)^{2}\right] \cdot\left[n \cdot \sum Y^{2}-\left(\sum Y\right)^{2}\right.}}
$$

Korelasi PPm dilambangkan dengan (r) dengan ketentuan nilai $r$ tidak lebih dari harga $(-1 \leq \mathrm{r} \leq+1)$. Apabila nilai $r=-1$ artinya korelasinya negatif sempurna; $r=0$ artinya tidak ada korelasi; dan $r=1$ berarti korelasinya sangat kuat.

Model path analysis digunakan untuk menganalisis pola hubungan antar variabel dengan tujuan untuk mengetahui pengaruh langsung maupun tidak langsung seperangkat variabel bebas (eksogen) terhadap variabel terikat (endogen). Berdasarkan pendapat Riduwan dan Engkos Achmad Kuncoro (2007:115), teknik analisis jalur akan digunakan dalam menguji besarnya sumbangan (kontribusi), yang ditunjukkan oleh koefisien jalur pada setiap diagram jalur dari hubungan kausal antar variabel X1, X2, X3 terhadap Y.

Berikut analisis jalur yang digunakan (Gambar 1):

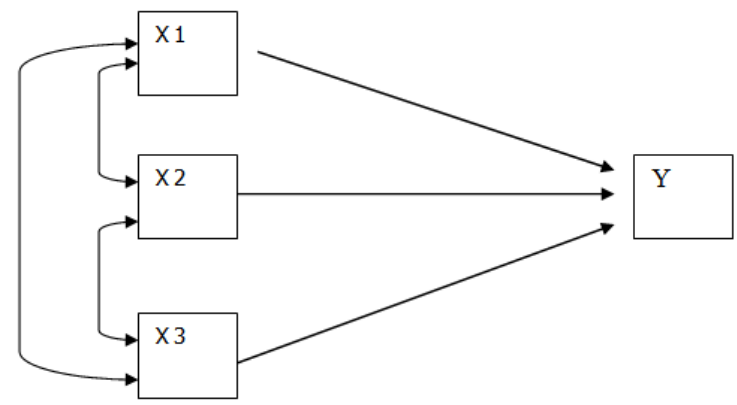

Gambar 1 Sub struktur 1 Hubungan Kausal X1, X2, dan X3 ke Y dengan menggunakan path analysis

Sumber: Data diolah berdasarkan analisis jalur

Di mana :

$\mathrm{X} 1=$ kreativitas

$\mathrm{X} 2$ = gaya kepemimpinan

$\mathrm{X} 3$ = kompetensi

$\mathrm{Y}=$ kepuasan kerja karyawan 


\section{HASIL DAN PEMBAHASAN}

Hipotesis yang diuji adalah (1) Kreativitas dan gaya kepemimpinan berkontribusi secara simultan dan signifikan terhadap kompetensi; dan (2) Kreativitas, gaya kepemimpinan, dan kompetensi berkontribusi secara simultan dan signifikan terhadap kepuasan kerja karyawan (Gambar 2).

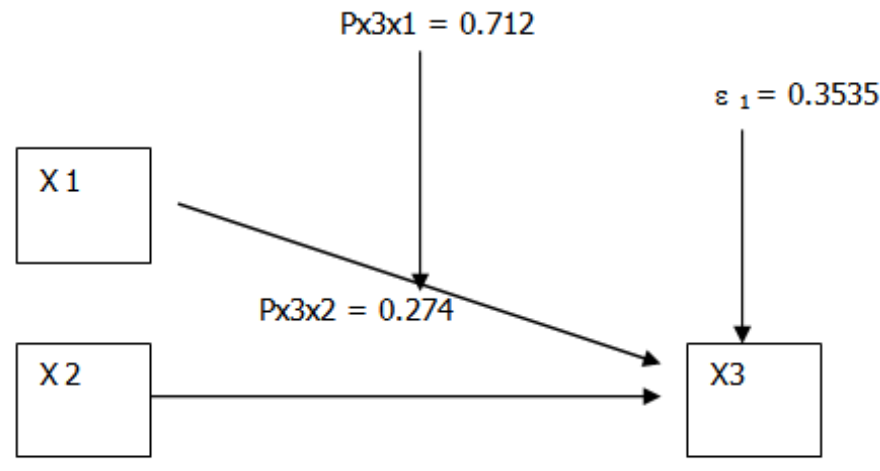

Gambar 2 Hubungan Kausal Empiris Sub-struktur 1 Variabel X1, X2 tehadap Variabel X3

Menguji Sub-struktur 2

$Y=\operatorname{Pyx}_{1} X_{1}+\operatorname{Pyx}_{2} X_{2}+\operatorname{Pyx}_{3} X_{3}+P \varepsilon_{2}$

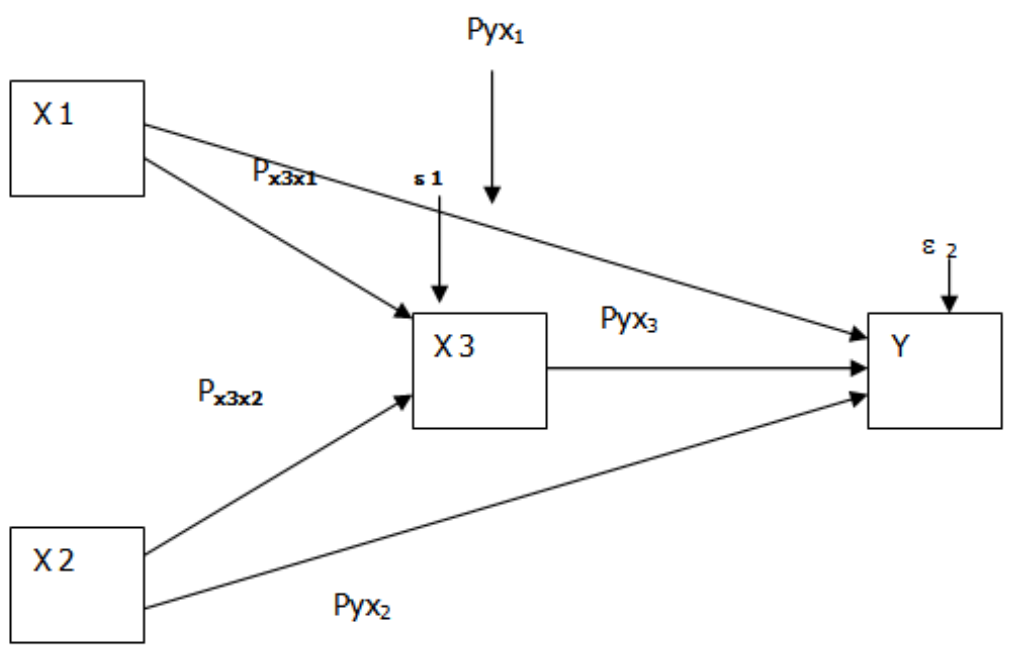




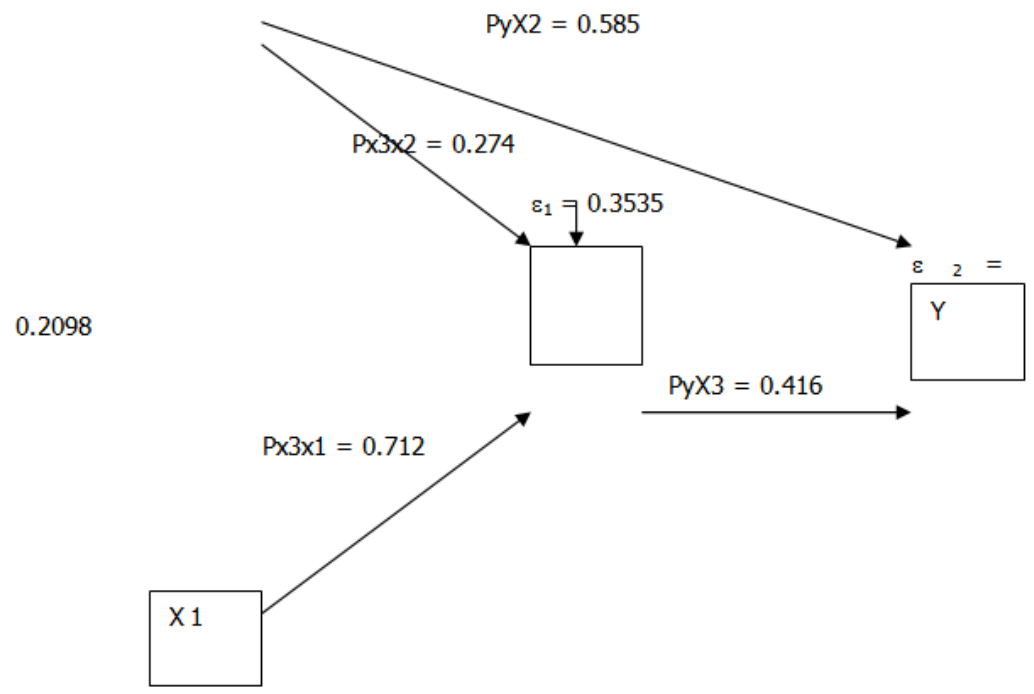

Gambar 3 Hubungan Kausal Empiris Variabel X1, X2, dan X3 terhadap Y

Hasil dari koefisien jalur pada sub-struktur 1 dan sub-struktur 2 berubah menjadi persamaan struktur, yaitu:

$$
\begin{aligned}
& \mathrm{X}_{3}=\mathrm{P}_{\mathrm{X} 3 \mathrm{X} 1}+{ }_{\mathrm{PX} 3 \mathrm{X} 2}+\mathrm{P}_{\mathrm{x} 3} \varepsilon_{1} \text { dan } \mathrm{R}_{\mathrm{x} 3 \mathrm{x} 1 \mathrm{x} 2} \\
& =0.712 \mathrm{X} 1+0.274 \mathrm{X} 2+0.3535 \varepsilon_{1} \text { dan } \mathrm{R}_{\mathrm{x} 3 \times 1 \times 2}^{2}=0.585 \\
& \mathrm{Y}=\mathrm{Py}_{\mathrm{X} 2 \mathrm{x} 2}+\mathrm{Py}_{\mathrm{X} 3 \mathrm{X} 3}+\mathrm{Py} \varepsilon_{2} \text { dan } \mathrm{R}^{2} \mathrm{Y}_{\mathrm{X} 3 \mathrm{X} 2} \\
& =0.585 \mathrm{X} 2+0.416 \mathrm{X} 3+0.2098 \varepsilon_{2} \text { dan } \mathrm{R}^{2} \mathrm{Y}_{\mathrm{X} 3 \mathrm{X} 2}=0.956
\end{aligned}
$$

Dengan diketahuinya seluruh koefisien jalur dari hubungan seperti yang digambar dalam Gambar 3, dapat diketahui pengaruh langsung dan pengaruh tidak langsung serta pengaruh total dan pengaruh bersama dari tiap-tiap variabel yang mempengaruhi variabel tertentu. Hasilnya dirangkum dalam Tabel 2 berikut ini:

Tabel 2 Rangkuman Pengaruh X1, X2, X3 Terhadap Y

\begin{tabular}{cccccc}
\hline Variabel & $\begin{array}{c}\text { Koefisien } \\
\text { Jalur }\end{array}$ & Langsung & $\begin{array}{c}\text { Tidak } \\
\text { Langsung } \\
\text { melalui X3 }\end{array}$ & Total & $\begin{array}{c}\text { Pengaruh } \\
\text { Bersama } \\
\left(\mathbf{R}^{2}{ }_{\text {YXk }} \text { ) }\right.\end{array}$ \\
\hline X1 & 0.712 & 0.712 & 0.416 & $0.712 \times 0.416=0.296$ & - \\
X2 $(1)$ & 0.274 & 0.274 & 0.416 & $0.274 \times 0.416=0.113$ & - \\
X2 $(2)$ & 0.585 & 0.585 & - & 0.585 & - \\
X3 & 0.416 & 0.416 & - & 0.416 & - \\
$\boldsymbol{\varepsilon}_{1}$ & 0.3535 & $0.3535^{2}=12,49$ & - & - & - \\
$\boldsymbol{\varepsilon}_{2}$ & 0.2098 & $0.2098^{2}=4.4$ & - & - & 0.956 \\
X2 dan & - & - & - & - & \\
X3 & & - & & & \\
\hline
\end{tabular}

Keterangan :

Kontribusi hasil sudah dikuadratkan

Pengaruh hasil yang belum dikuadratkan 
Berdasarkan hasil perhitungan analisis jalur struktural di atas, maka memberikan informasi secara objektif sebagai berikut. Pertama, pengaruh tidak langsung kreativitas (X1) terhadap kepuasan kerja karyawan (Y) melalui kompetensi (X3) sebesar 0.296. Dengan demikian, pengaruh total kreativitas (X1) terhadap kepuasan kerja karyawan (Y) sebesar 0.296 sehingga peranan kreativitas (X1 ) mempengaruhi kepuasan kerja karyawan (Y) sebesar 0.712 dan berbanding lurus atau searah karena $(+)$. Artinya, jika kreativitas (X1) diberi penambahan nilai 1, maka kepuasan kerja karyawan (Y) akan bertambah sebesar $0.712^{2}=50.6 \%$ dan begitu seterusnya. Besarnya kontribusi kreativitas (X1) secara langsung mempengaruhi kepuasan kerja karyawan (Y) adalah sebesar 0.712 dan secara tidak langsung kreativitas (X1) mempengaruhi kepuasan kerja karyawan (Y) melalui kompetensi adalah sebesar 0.416 .

Kedua, pengaruh tidak langsung gaya kepemimpinan (X2) terhadap kepuasan kerja karyawan (Y) melalui kompetensi (X3) sebesar 0.113. Dengan demikian, pengaruh total gaya kepemimpinan (X2) terhadap kepuasan kerja karyawan (Y) sebesar 0.113 sehingga peranan gaya kepemimpinan (X2) mempengaruhi kepuasan kerja karyawan (Y) sebesar 0.274 dan berbanding lurus atau searah karena $(+)$. Artinya, jika gaya kepemimpinan (X2) diberi penambahan nilai 1, maka kepuasan kerja karyawan (Y) akan bertambah sebesar $0.274^{2}=7.50 \%$ dan begitu seterusnya. Besarnya kontribusi gaya kepemimpinan (X2) secara langsung mempengaruhi kepuasan kerja karyawan (Y) adalah sebesar 0.274 dan secara tidak langsung gaya kepemimpinan (X2) mempengaruhi kepuasan kerja karyawan (Y) melalui kompetensi adalah sebesar 0.416. Ketiga, peranan gaya kepemimpinan (X2) mempengaruhi kepuasan kerja karyawan $(\mathrm{Y})$ sebesar 0.585 dan berbanding lurus atau searah karena (+). Artinya, jika gaya kepemimpinan (X2) diberi penambahan nilai 1, maka kepuasan kerja karyawan (Y) akan bertambah sebesar 0.585 dan begitu seterusnya. Besarnya kontribusi gaya kepemimpinan (X2) secara langsung mempengaruhi kepuasan kerja karyawan $(\mathrm{Y})$ sebesar $0.585^{2}=34.2 \%$.

\section{SIMPULAN}

Berdasarkan uraian serta hasil dan analisis sebelumnya mengenai analisis pengaruh kreativitas, gaya kepemimpinan, dan kompetensi terhadap kepuasan kerja karyawan, maka dapat diambil kesimpulan, sebagai berikut. Pertama, dari penilaian karyawan akan kedua dimensi kreativitas PT Interdata Bhakti Mulya, yaitu kreativitas dengan tipe dimensi proses dan kreativitas dengan tipe dimensi person, maka karyawan menilai netral terhadap kreativitas dengan tipe dimensi proses. Kedua, dari ketiga gaya kepemimpinan, yaitu authocratic, democratie, dan laisser-faire, maka perilaku yang diterapkan oleh pimpinan PT Interdata Bhakti Mulya menurut penilaian karyawan adalah gaya kepemimpinan tipe Authocratic dan Laisser-faire. Ketiga, dari penilaian karyawan akan ketiga dimensi kompetensi PT Interdata Bhakti Mulya, yaitu kompetensi tipe behaviourist, constructivist, dan Smr viewpoint, maka karyawan menilai setuju dengan kompetensi tipe Behaviourist yang diterapkan di perusahaan. Keempat, kreativitas berpengaruh dan berkontribusi secara signifikan terhadap kepuasan kerja karyawan PT Interdata Bhakti Mulya sebesar 68.6\%. Dapat diartikan bahwa dengan karyawan memiliki kreativitas yang baik, maka dapat memberikan pengaruh terhadap kepuasan kerja karyawan. Kelima, gaya kepemimpinan berpengaruh dan berkontribusi secara signifikan. 139 terhadap kepuasan kerja karyawan PT Interdata Bhakti Mulya sebesar 92.5\%. Dapat diartikan bahwa dengan gaya kepemimpinan diterapkan dengan baik, maka akan memberikan pengaruh terhadap kepuasan kerja karyawan. Keenam, kompetensi berpengaruh dan berkontribusi secara signifikan terhadap kepuasan kerja karyawan PT Interdata Bhakti Mulya sebesar 89.5\%. Dapat diartikan bahwa dengan memiliki kompetensi yang baik, maka akan memberikan pengaruh terhadap kepuasan kerja karyawan. Ketujuh, kreativitas, gaya kepemimpinan, dan kompetensi berpengaruh dan berkontribusi secara signifikan terhadap kepuasan kerja karyawan sebesar 58.5\%. Dapat diartikan bahwa dengan menerapkan kreativitas dengan baik, maka gaya kepemimpinan diterapkan dengan baik dan mempunyai kompetensi yang baik dapat memberikan pengaruh terhadap kepuasan kerja karyawan. 
Berdasarkan uraian serta hasil dan analisis pada bab-bab sebelumnya mengenai analisis pengaruh kreativitas, gaya kepemimpinan, dan kompetensi terhadap kepuasan kerja karyawan, maka dapat diambil kesimpulan, sebagai berikut. Pertama, hasil pengolahan dan analisis data menunjukkan bahwa penilaian kreativitas oleh karyawan PT Interdata Bhakti Mulya memberikan kontribusi yang cukup besar terhadap kepuasan kerja karyawan, namun kontribusi ini dirasa masih dapat ditingkatkan lagi. Hasil temuan penelitian ini diperlukan upaya-upaya untuk memperbaiki kreativitas agar tujuan dari kreativitas dapat mencapai tujuan sehingga dapat meningkatkan kepuasan kerja karyawan. Upayaupaya tersebut antara lain dengan cara kayawan diberi kesempatan untuk mengikuti seminar-seminar, workshop, dan pelatihan secara berkala yang dapat bermanfaat untuk mengembangkan potensi kreativitas yang dimiliki. Kedua, hasil pengolahan data dan analisis data menunjukkan bahwa gaya kepemimpinan yang diterapkan di PT Interdata Bhakti Mulya memberikan kontribusi yang cukup besar terhadap kepuasan kerja karyawan, namun kontribusi ini dirasa masih dapat ditingkatkan lagi. Hasil temuan penelitian ini diperlukan upaya-upaya untuk memperbaiki gaya kepemimpinan agar tujuan dari gaya kepemimpinan yang diterapkan dapat mencapai tujuan sehingga dapat meningkatkan kepuasan kerja karyawan. Upaya-upaya tersebut antara lain dengan cara (1) Pimpinan diberikan kesempatan untuk mengikuti seminar-seminar kepemimpinan atau leadership secara berkala sehingga dapat mengembangkan dan meningkatkan gaya kepemimpinannya; dan (2) Pimpinan sebaiknya sedikit melepaskan gaya authocratic dan gaya Laisser-faire yang masih terkandung dalam gaya kepemimpinannya. Dengan begitu, maka kepuasan kerja karyawan akan dapat lebih terpenuhi jika tidak terlalu dibatasi oleh prosedur-prosedur yang selama ini dijadikan landasan pemimpin dalam bertindak dan mengambil keputusan; dan sebaiknya pemimpin lebih menjalin hubungan yang lebih erat lagi antara atasan dan bawahannya sehingga dapat memberikan peningkatan kinerja karyawan yang dapat memberikan pencapaian kepuasan kerja karyawan. Ketiga, hasil pengolahan data dan analisis data menunjukkan bahwa kompetensi yang diterapkan di PT Interdata Bhakti Mulya memberikan kontribusi yang cukup besar terhadap kepuasan kerja karyawan, namun kontribusi ini dirasa masih dapat ditingkatkan lagi. Hasil temuan penelitian ini diperlukan upaya-upaya untuk memperbaiki kompetensi agar tujuan dari kompetensi yang diterapkan dapat mencapai tujuan sehingga dapat meningkatkan kepuasan kerja karyawan. Upaya-upaya tersebut antara lain dengan jalan kayawan diberi kesempatan untuk mengikuti seminar-seminar, workshop, dan pelatihan secara berkala yang dapat bermanfaat untuk mengembangkan dan mengasah potensi kompetensi yang dimiliki.

\section{DAFTAR PUSTAKA}

Engko, C., dan Gudono. (2007). Jurnal Akuntansi dan Auditing Indonesia, 11(2), Universitas Pattimura dan Universitas Gadjah Mada.

Exxceed. Inc (2002). Competency based human resource management. Retrieved March 9, 2006, from http://www.exxceed.com/web/products/dictionary.html.

Greenberg, J., ang Baron, R. (2003). Behavior in organizations (understanding and managing the human side of work), $8^{\text {th }}$ ed., Prentice Hall.

Griselda, G., dan Panjaitan, T.M. (2007). Derema Jurnal Manajemen, 2(1), Fakultas Ekonomi, Universitas Pelita Harapan, Karawaci-Tangerang.

Hadi, S. (2007). Derema, Jurnal Akuntansi dan Auditing Indonesia, 11(2), Fakultas Ekonomi, Universitas Islam Indonesia.

Kartono, K. (2006). Pemimpin dan kepemimpinan, Jakarta: PT Raja Grafindo Persada. 
Lasmahudi, A. (2002). Competency based human resource management. Retrieved March 9, 2006, from http://www.e-psikologi.com/manajemen/111202.html.

Lovelock, C.H (2005). Manajemen pemasaran jasa, Jakarta: PT Indeks kelompok Gramedia.

Lucia, A.D., and Lepsinger, R. (2000). The art and science of competency model, San Fransisco: Jossey-Bass / Pfeiffer.

Mathis, R.L., dan Jackson, J.H. (2004). Manajemen sumber daya manusia, edisi kesepuluh, Jakarta: Salemba Empat.

Pratisto, A. (2005). Cara mudah mengatasi masalah statistik dan rancangan percobaan dengan SPSS 12, Jakarta: PT Elex Media Komputindo Kelompok Gramedia.

Retnowati, W., dan Hanifah, I.A. (2008). Telaah manajemen, Jurnal Riset dan Konsep Manajemen, 3(1), Universitas Katolik Indonesia Atma Jaya.

Riduwan dan Kuncoro, E.A. (2007). Cara menggunakan dan memakai analisis jalur (path analysis), Bandung: Alfabeta.

Robbins, S.P., dan Coulter, M. (2004). Manajemen, jilid pertama dan kedua, edisi ketujuh, Jakarta: PT Indeks kelompok Gramedia.

Schoonover Associates. (2003). Competency based human resource management. Retrieved March 9, 2006, from http://www.schoonover.com/competency faqs.html.

Simamora, B. (2004). Panduan riset perilaku konsumen, Jakarta: PT Gramedia Pustaka Utama.

Simamora, B. (2004). Riset pemasaran (falsafah, teori, dan aplikasi), Jakarta: PT Gramedia Pustaka.

Sugiyono. (2005). Metode penelitian bisnis, Bandung: CV Alphabeta.

Supriadi, D. (1994). kreativitas, kebudayaan, dan perkembangan iptek, Bandung: Alfabeta.

Umar, H. (2005). Riset pemasaran dan perilaku konsumen, Jakarta: Gramedia Pustaka Utama.

Wibowo, P. M. (2007). Manajemen kinerja, Jakarta: Raja Grafindo Perkasa. 